\title{
ArcheoSciences
}

Revue d'archéométrie

\section{Atomic Disorder in Fossil Tooth and Bone Mineral: An FTIR Study Using the Grinding Curve Method}

Désordre structural dans la partie minérale des os et dents fossiles : une étude

IRTF basée sur la méthode des courbes de broyage

\section{Y. Asscher , L. Regev, S. Weiner and E. Boaretto}

\section{CpenEdition}

\section{Journals}

Electronic version

URL: https://journals.openedition.org/archeosciences/3062

DOI: 10.4000/archeosciences.3062

ISBN: 978-2-7535-1849-0

ISSN: 2104-3728

\section{Publisher}

Presses universitaires de Rennes

\section{Printed version}

Date of publication: 30 April 2011

Number of pages: 135-141

ISBN: 978-2-7535-1847-6

ISSN: 1960-1360

\section{Electronic reference}

Y. Asscher , L. Regev, S. Weiner and E. Boaretto, "Atomic Disorder in Fossil Tooth and Bone Mineral: An FTIR Study Using the Grinding Curve Method", ArcheoSciences [Online], 35 | 2011, Online since 30 April 2013, connection on 01 March 2022. URL: http://journals.openedition.org/archeosciences/3062 ; DOI: https://doi.org/10.4000/archeosciences.3062 


\title{
Atomic Disorder in Fossil Tooth and Bone Mineral: An FTIR Study Using the Grinding Curve Method
}

\author{
Désordre structural dans la partie minérale des os et dents fossiles : \\ une étude IRTF basée sur la méthode des courbes de broyage
}

\author{
Y. Asscher*, L. RegeV*, S. Weiner* and E. Boaretto**
}

\begin{abstract}
Bone and tooth mineral generally undergo diagenetic changes. These changes in the carbonate hydroxyapatite structure and composition can affect the signals embedded in the mineral phase, such as migration behavior, age of the specimen and the reconstruction of past environments. Mineral preservation state can be assessed using infrared spectroscopy which provides information on crystal disorder at the atomic level and mineral composition. Here we present a new approach to evaluate carbonate hydroxyapatite atomic disorder using infrared spectroscopy and the standard $\mathrm{KBr}$ sample mounting method. We show that by repeated grinding of the sample and then plotting the infrared splitting factor against the width of the major phosphate absorption peak after each grinding, grinding curves with well defined trend lines can be obtained. The offsets between curves reflect differences in atomic disorder. We show that grinding curve offsets can be used to evaluate the state of preservation of bone, dentine and enamel mineral.
\end{abstract}

Résumé : Les os et les dents subissent généralement des changements diagénétiques. Ces changements de la structure et de la composition de l'hydroxyapatite carbonatée peuvent affecter les signaux inclus dans la phase minérale, tels que les comportements de migration, l'àge des spécimens ou la reconstitution des environnements passés. L'état de préservation de la phase minérale peut être déterminé par la spectrométrie infrarouge qui fournit des informations sur le désordre structural et sur la composition du minéral. Dans cette étude, nous présentons une nouvelle approche permettant d'évaluer le désordre cristallin en utilisant la spectrométrie infrarouge. Nous montrons ici qu'un broyage répété de l'échantillon et la représentation graphique des valeurs de splitting factor et de la largeur à mi-hauteur de la principale bande d'absorption des phosphates après chaque broyage, peut permettre de définir des courbes de broyage avec des tendances bien définies. Un décalage entre ces courbes reflète des différences de désorganisation à l'échelle atomique.

Nous montrons qu'un décalage entre les courbes de broyage peut être utilisé pour évaluer l'état de préservation de la phase minérale des os et dents fossiles.

Keywords: crystal disorder, fossil bone, fossil teeth, grinding curve.

Mots clé : désordre du cristal, os fossile, dent fossile, courbes de broyage.

\section{INTRODUCTION}

The archaeological record is composed of a diversity of materials, some of which enable us to reconstruct aspects of past human life. Among the more important of these materials are biological mineralized tissues, such as bones and teeth, as they contain information about the living animal, and the environment in which it lived.

\footnotetext{
* Department of Structural Biology and the Kimmel Center for Archaeological Science, Weizmann Institute of Science, Rehovot 76100, Israel. (yotam. asscher@weizmann.ac.il)

** Radiocarbon and Cosmogenic Isotopes Laboratory, Kimmel Center for Archaeological Science, Weizmann Institute of Science, 76100 Rehovot, Israel.
} 


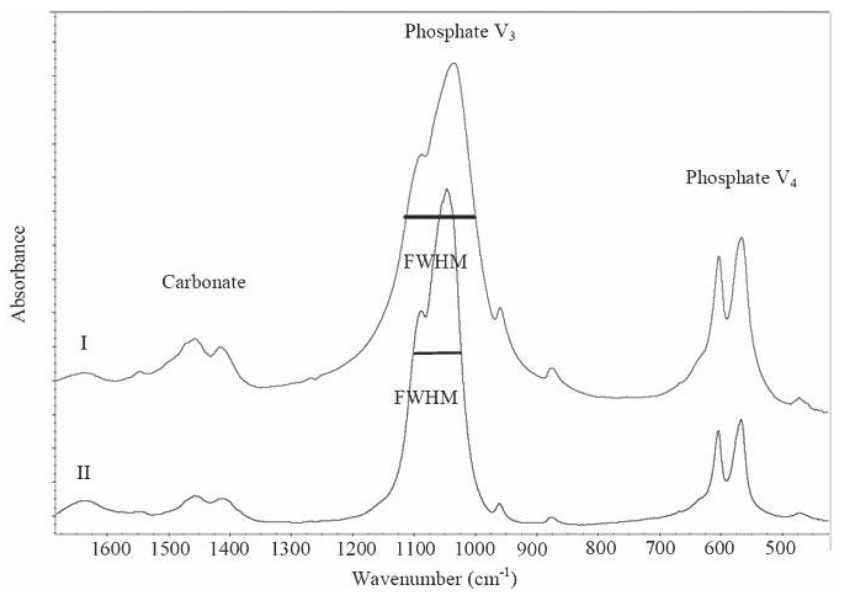

Figure 1: Plot of the change in peaks width with grinding for a human molar enamel sample (adapted from Asscher 2011). Showing the change in IRSF values from 3.6 to 4.2 for I - sample that was least intensively ground, II - sample that was most intensively ground. FWHM - full width at half maximum.

Figure 1: Graphe présentant le changement dans la largeur des pics du meulage d'échantillons d'émail humaine (adapté de Asscher 2011). Les changements dans les valeurs de IRSF de 3.6 a 4.2 sont présentés pour I - échantillon qui a été le moins intensivement moulu, II échantillon qui a été le plus intensivement moulu. FWHM - largeur complète à la moitie du maximum

Embedded in the bone and tooth minerals are isotopic and chemical signals that can provide information on paleoclimatology (Longinelli, 1984; Luz, Kolodny et al., 1984; Wang, Wang et al., 2008), migration of humans or other animals (Price, Grupe et al., 1994; Britton, Grimes et al., 2009), chronology (Hedges, LeeThorp et al., 1995; Milton, Kramer et al., 1997; Grün, 2001; Wild, Teschler-Nicola et al., 2005), paleoenvironment (Feranec and MacFadden 2000), paleodiet (Lee-Thorp, 2002) and chemical alteration post mortem (Wang and Cerling, 1994; Zazzo, Lecuyer et al., 2004; Dauphin, Montuelle et al., 2007; Roche, Segalen et al., 2010). All these applications can only provide reliable information if the biogenic mineral has undergone only minimal changes after burial (diagenesis).

The mineral phase in mature vertebrate bone and tooth is carbonated hydroxyapatite. This mineral is particularly susceptible to substitutions of carbonate, chloride, fluoride, magnesium and other ions into its crystal lattice. These substitutions introduce disorder at the atomic level and hence destabilize the mineral. Furthermore, the crystals of the bone family of materials (Posner, 1969, Weiner and Wagner, 1998), namely bone, dentin, cementum, mineralized tendon etc, are all extremely small, with average crystal sizes being tens of nanometers long and wide and only $2-4 \mathrm{~nm}$ thick. These crystals thus have a high surface to bulk ratio

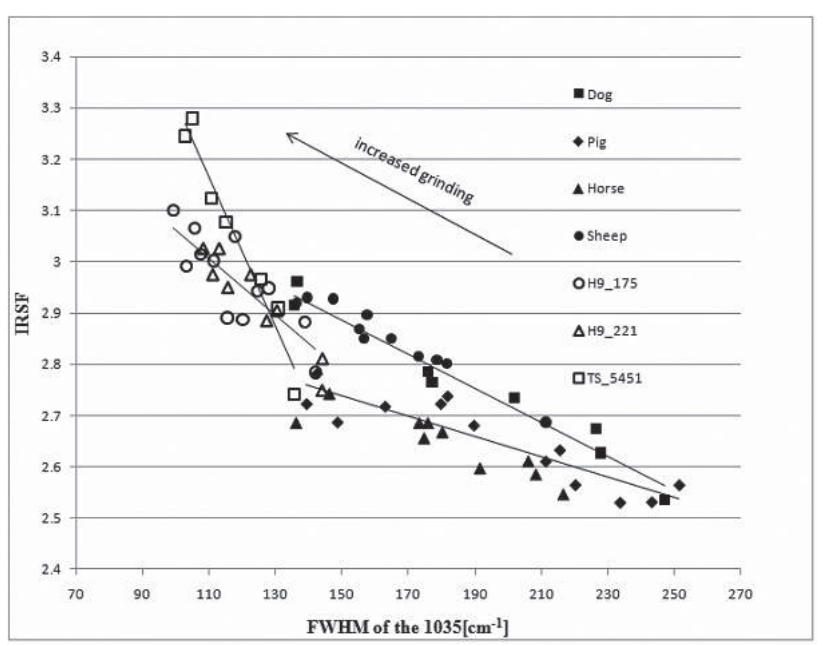

Figure 2: Grinding curves of fresh mandible bone from different taxa, and archaeological bones. H9_221 and H9_175 are goat bones from Megiddo site, dated to around 2800 years ago. TS_5451 is a mandible from Tel es-Safi site, dated to around 3,200 years ago.

Figure 2: Courbes du meulage de l'os d'une mandibule de différents taxons, et d'os archéologiques. H9-221 et H9-175 sont des os de chèvres du site de Megiddo datés d'il y a 3200 ans à peu près.

and hence a large proportion of the atoms at or close to the surface are disordered. This too can destabilize these crystals. Thus the crystals in the bone family of materials readily undergo diagenetic change after burial. In contrast the crystals of tooth enamel are orders of magnitude larger than those of the bone family of materials, and are thus generally thought to be more stable and less prone to diagenesis.

During diagenesis the general trend is for the carbonated hydroxyapatite crystals to become more ordered at the atomic level and hence more stable. This involves ion substitutions such as fluoride uptake (Eanes and Reddi, 1979) and endogenous reorganization of the planar carbonates that replace the tetrahedral phosphates and the hydroxyl groups (Sponheimer and Lee-Thorp, 1999). The crystals of the bone family of materials also increase their size, presumably by a ripening process whereby the larger crystals grow at the expense of the smaller crystals. These changes can be conveniently monitored by Fourier Transform Infrared (FTIR) Spectroscopy.

Termine and Posner (Termine and Posner, 1966) showed that the extent to which the absorptions at $603 \mathrm{~cm}^{-1}$ and $567 \mathrm{~cm}^{-1}$ are split in the infrared spectrum, is an indication of the crystallinity of the carbonated hydroxyapatite. Crystallinity refers to a combination of the crystal size and the atomic disorder. The manner in which this so-called "splitting factor" is generally calculated was defined by Weiner and 
Bar-Yosef (Weiner and Bar-Yosef, 1990). Crystals in fresh bone have infrared splitting factor (IRSF) values of $2.7 \pm 0.2$ and calcined bone can have values around 7 (Stiner, Kuhn $e t$ al., 1995). Modern enamel is reported to have IRSF values around 4 (Weiner, 2010). In fossil bone the IRSF increases because of diagenesis and values as high as 6 to 7 have been reported (Stiner, Kuhn et al., 1995). The large majority of values of fossil bone and tooth mineral are however between 2.7 and 4 to 4.5. Trueman $e t$ al. (Trueman, Behrensmeyer $e t$ al., 2003) pointed out that bones with an IRSF value above 3.3 have lost most of their collagen. This provides space for additional growth in size of the crystals, which in turn results in higher IRSF values (Trueman, Behrensmeyer et al., 2003). Studies on the diagenetic changes in fossil enamel also show higher IRSF values. (Lee-Thorp and Sponheimer 2003; Roche, Segalen et al., 2010).

The measurement of the IRSF value of carbonated hydroxyapatite using the standard $\mathrm{KBr}$ pellet method is influenced by the extent to which the sample is ground and the way the sample is ground (Surovell and Stiner, 2001). Surovell and Stiner (2001) noted a small decrease in the IRSF of the powder fraction with increased grinding, and in two cases they observed an increase. The fact that particle size influences the width of infrared absorption peaks is a general phenomenon, with the smaller the particle size, the narrower the peaks (Ruppin and Englman, 1970). The particle size effect would therefore be expected to result in an increase in IRSF with increased grinding due to the narrowing of the peaks. We therefore do not understand the results reported by Surrovell and Stiner (2001). In contrast, atomic disorder causes the infrared radiation to be absorbed by the sample over a larger range of wavelengths, and this in turn causes peak broadening. Thus the two affects work in opposite ways, making it difficult to extract reliable information on the extent of atomic disorder that exists in the crystalline material being analysed. Regev et al. (Regev, 2010) showed empirically for calcite that if the sample is repeatedly ground, and after each grinding a spectrum is obtained, then a plot of the heights of two of the absorption peaks in the calcite spectrum after normalizing to the height of the third peak, shows a distinct trend line. Furthermore, calcites formed in different ways (geogenic calcite, ash and plaster) all have different trend lines. A theoretical analysis of these observations provides insights into the factors responsible for the changes in peak width due to grinding, and shows that the further the trend lines are offset from the very well ordered sparry calcite trend line, the more disordered are the crystals (Poduska, 2010).

Asscher et al. (2011) used a similar approach for studying atomic disorder in modern enamel samples, as well as modern bone, dentine and cementum crystals. Asscher et al (2011) showed that when the IRSF is plotted against the full width at half maximum of the $1035 \mathrm{~cm}^{-1}$ peak of carbonated hydroxyapatite, as a function of grinding, different trend lines are obtained for the bone family of minerals and enamel. Furthermore, the trend lines for modern enamel from various taxa are different, implying that the disorder within these crystals is different. Here we use the same approach to better understand mineral diagenesis of fossil bone and teeth mineral.

\section{Methods}

Fresh enamel, dentine, mandible bone and cementum were obtained from different taxa: Bos taurus (cow), Sus scrofa domestica (pig), Ovis aries (sheep), Equus caballus (horse), Canis familiaris (dog) and Capra hircus (goat). All the examined teeth were permanent and fully erupted. No sex differentiation was carried out and all the teeth were mature. Bovine samples were obtained from a slaughterhouse; equine samples were obtained from a veterinary hospital, human samples were provided by Dr Sunita Ho, University of California San Francisco with the necessary

\begin{tabular}{|c|c|c|c|c|c|c|}
\hline Sample & Tissue & Species & Site & Area & Locus & $\begin{array}{c}\text { Approx. Age } \\
{[\text { Years] }}\end{array}$ \\
\hline H9_175 & Bone & goat & Megiddo & H9 & 62 & 2800 \\
\hline H9_221 & Bone & goat & Megiddo & H9 & 56 & 2800 \\
\hline TS_5451 & Mandible & bovid & Tel es-Safi & A3 & 91012 & 3200 \\
\hline Unclear Context & Tooth & equid & Qesem & - & - & $200-400,000$ \\
\hline 2049 & Tooth & equid & Neve-Yarak & A2401 & 228 & 8,000 \\
\hline 3111 & Tooth & equid & Ateret & E3 & 321 & 900 \\
\hline
\end{tabular}

Table 1: Archaeological samples and their locations.

Tableeau 1 : Échantillons archéologiques et leurs localisations. 
approvals. Table 1 lists the archaeological samples that were collected from sites in Israel, namely Tel es-Safi, Ateret, Megiddo, Neve Yarak and Qesem cave.

Modern bone samples were taken from the mandible, several centimeters away from the closest tooth. Archaeological bone samples were from the cortices of long bones. The modern bones were kept frozen until sampling and neither modern nor archaeological bones were chemically treated prior to grinding.

Tooth crowns were removed from the root and cut in half with a Dremel saw, and the outer layers were then inspected using a binocular for external deformations and plaque contaminations. These contaminations were removed by a water-cooled dental drill prior to tissue sampling. Tooth mineralized tissues were separated by a water-cooled dental drill, using a diamond bur. The water spray, containing the tissue particles, was collected in a plastic bag, then emptied in a $50 \mathrm{ml}$ tube, and separated by centrifugation. The pellet was then washed with ethanol and left to air dry.

All FTIR spectra were obtained with a Nicolet 380 instrument at $4 \mathrm{~cm}^{-1}$ resolution. A mortar and a pestle were used for grinding. The sample was lightly ground by hand, mixed with $\mathrm{KBr}$ powder and pressed to form a transparent pellet under 2 tons. After obtaining the spectrum, the pellet was reground, pressed and another spectrum was obtained. The process was repeated until no significant changes in peak shapes were obtained. The IRSF was calculated by summing the heights of the $565 \mathrm{~cm}^{-1}$ and $603 \mathrm{~cm}^{-1}$ peak heights and dividing the sum by the height of the valley between them (Weiner and Bar-Yosef, 1990). The full width at half maximum (FWHM) of the $v_{3}$ absorption peak was measured directly off the spectrum.

\section{RESULTS}

In order to decouple the particle size effect from the effect of atomic disorder, the IRSF values are plotted against the $v_{3}$
FWHM as a function of repeated grinding. Trend lines that document the grinding effect on the carbonated hydroxyapatite crystals are produced. Figure 2 shows grinding curves of fresh bones from different taxa, as well as fossil bones that differ in their preservation states. Using the grinding curve approach, we note that the modern sheep and dog bones have similar trend lines, whereas the pig and horse bones fall on a different trend line. This indicates that these modern bones are formed with different degrees of atomic disorder. The grinding curves for the fossil bones have FWHM values that are for the most part smaller than for the modern bones, and the slopes of the trend lines are significantly higher than the slopes for modern bones.

A whole bovid fossil mandible was found in Tel es-Safi (2007) and a molar tooth was extracted from this mandible. Figure 3 shows grinding curves for the mandible bone, as well as the dentine and enamel of the molar tooth. For comparison, the grinding curves of modern bovid mandible bone, and modern dentine and enamel from a molar, are shown. We note that modern bone and modern dentin have different trend lines. The fossil mandibular bone and dentin trend lines are significantly offset from the modern trend lines, indicating that diagenesis has occurred. Surprisingly, the fossil dentin trend line is in the same region as the enamel curves, suggesting extreme diagenesis. The fossil enamel curve is offset to higher IRSF values than the modern enamel curve, again indicating that diagenesis has taken place.

Figure 4 shows grinding curves of 3 fossil equid enamel samples from teeth of different ages, compared to modern equid enamel. Deviations from the modern grinding curve show that the archaeological samples are more ordered and therefore have undergone significant diagenesis. There is no direct correlation between extent of diagenesis and time of burial. Figure 5 shows the grinding curves of equid dentine from the same fossil teeth, as shown in Figure 4. Again the younger Ateret sample is more poorly preserved than the older Neve Yarak sample. The very old Qesem sample is the least well preserved.

\begin{tabular}{|c|c|c|c|}
\hline Enamel (site name) & Trend line equation & IRSF at FWHM=100 & degree of alteration [\%] \\
\hline Qesem & $y=-0.018 x+6.0$ & $4.2 \pm 2.5 \%$ & $13 \%$ \\
\hline Ateret & $y=-0.021 x+6.1$ & $4.0 \pm 4.2 \%$ & $8 \%$ \\
\hline Neve-Yarak & $y=-0.017 x+5.5$ & $3.8 \pm 3.8 \%$ & $3 \%$ \\
\hline Modern & $y=-0.015 x+5.2$ & $3.7 \pm 2.7 \%$ & $0 \%$ \\
\hline
\end{tabular}

Table 2: Degree of alteration of fossil enamel from teeth found in 3 archaeological sites. Ateret, by historical references is dated to 1099 CE , Qesem cave, dated to 400,000-200,000 years ago , Neve-Yarak site is dated to 8,000 years ago.

Tableau 2 : Degré d'altération de l'émail fossilisée trouvée dans 3 sites archéologiques, Ateret selon les références historiques de 1099 EC, la cave Qesem, datée il y a 400000 a 200000 ans, le site de Neve-Yarak date d'il y a 8000 ans. 


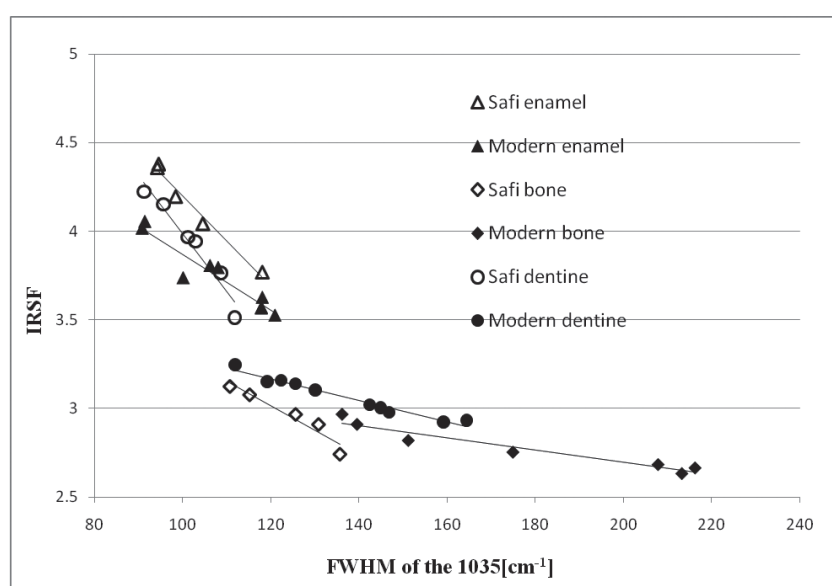

Figure 3: Grinding curves of enamel, dentine and bone from a modern bovid mandible and from a fossil bovid mandible found in Tel es-Safi site, dated to around 3,200 years ago.

Figure 3 : Courbes du meulage d'email, de dentine et d'os appartenant a des mandibules de bovidés récents et de bovidés fossilisés trouvés dans le site Tel es-Safi de différents sites datés d'il y a 3200 à peu près.

\section{DisCusSion}

This study shows that the use of grinding curves for studying atomic disorder in modern bones and teeth as developed by Asscher et al. (2011), can be applied to fossil bones and teeth in order to monitor mineral preservation states. Diagenesis clearly causes a change in both the FWHM of the $1035 \mathrm{~cm}^{-1}$ peak, as well as changes in the IRSF. The use of the grinding curve approach significantly increases the sensitivity of using infrared spectra for monitoring diagenesis, as compared to the IRSF alone. The method is simple and rapid, taking around 30 minutes to produce a single grinding curve.

We note here that the grinding curves for modern dentin and mandibular bone are offset (Fig. 2), and that bone mineral from different taxa also have offset grinding curves (Fig. 1). This implies that these mineralized tissues have crystals with different size/atomic disorder properties. Such differences have not been reported to date.

In general the trends observed here for fossil carbonate hydroxyapatite samples are that the FWHM values are much smaller than those for the modern counterparts, and the IRSF values are higher. The slopes of the grinding curves increase with poorer preservation. Three different properties of the samples contribute to these trends: the particle size due to grinding, the size of the crystals in the mineralized tissue and the atomic disorder within these crystals. The theoretical study of calcites by Poduska et al. (Poduska,

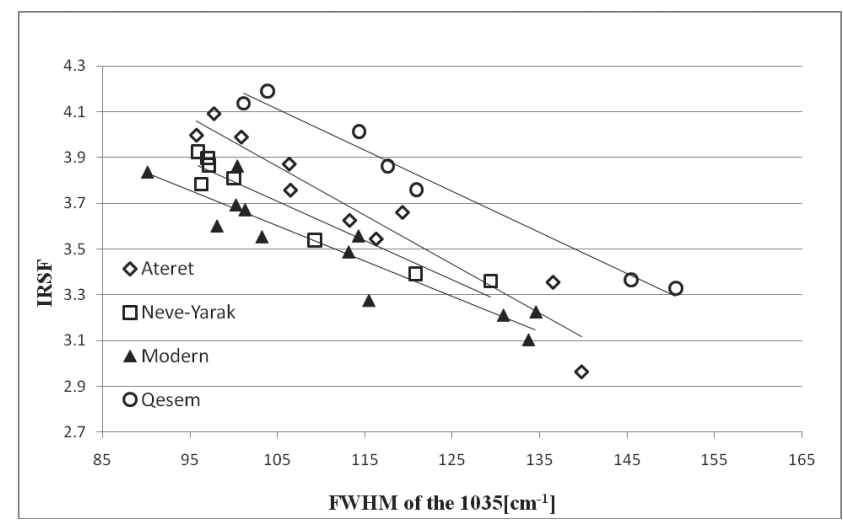

Figure 4: Grinding curves of equid enamel from different sites. Ateret, by historical references is dated to 1099 CE (Common Era), Qesem cave site, dated to 400,000-200,000 years ago, NeveYarak site is dated to 8,000 years ago.

Figure 4 : Courbes du meulage d'émail d'équidés provenant de différents sites. Ateret, selon les références historiques de 1099 EC, Qesem, datée il y a 400000 a 200000 ans, le site de Neve-Yarak date d'il y a 8000 ans.

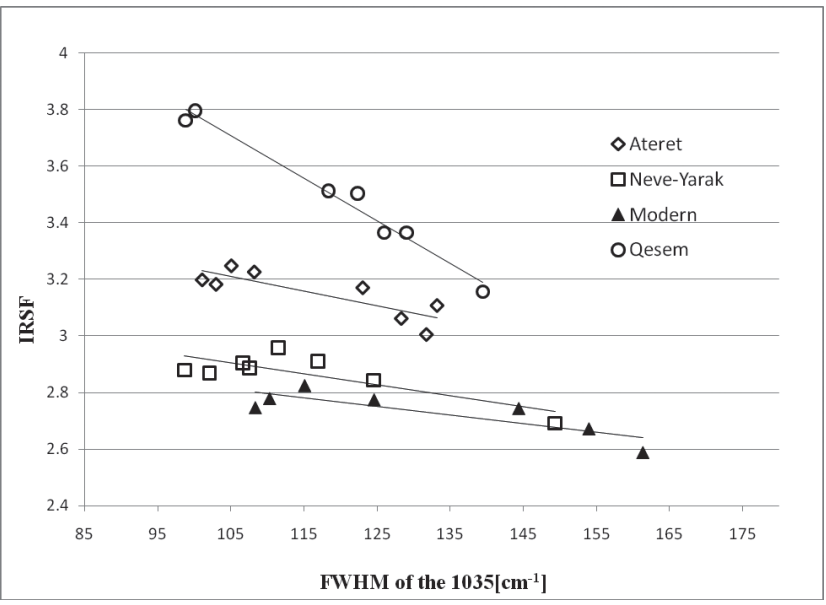

Figure 5: Grinding curves of equid dentine from different sites. Ateret, by historical references is dated to $1099 \mathrm{CE}$, Qesem cave site, dated to 400,000-200,000 years ago, Neve-Yarak site is dated to 8,000 years ago.

Figure 5: Courbes du meulage de dentine d'équidés provenant de différents sites. Ateret, selon les références historiques de 1099 EC, Qesem, datée il y a 400000 a 200000 ans, le site de Neve-Yarak date d'il y a 8000 ans.

2010), explains the particle size effect, and shows that atomic disorder is responsible for the offsets of the grinding curves. In this study, we can also attribute the offsets to the contribution of atomic disorder, but in addition there is a crystal size effect. The latter is prominent for the crystals of bone and dentin which are a priori extremely small, and 
hence have a strong tendency to increase their stability by increasing their size and hence decreasing their surface to bulk ratios. Trueman et al. (Trueman, Behrensmeyer et al., 2004) showed directly that crystal sizes in sub-fossil bones do increase, and this is in part reflected in an increase in their IRSF values. The crystal size effect can be expected to be absent or minimal for the very large crystals of enamel. The offsets in the enamel crystal grinding curves as a function of diagenesis can mainly be attributed to compositional changes, such as the loss of carbonates with time that result in an increase in atomic disorder.

This study clearly shows that enamel mineral can undergo diagenesis, and therefore applications using enamel need to take into account the possibility that the enamel being analysed is poorly preserved and the signal obtained may have been altered. Most studies to date using fossil enamel have not taken diagenesis into account. Furthermore, a correlation was found between the preservation states of enamel and dentine within the same fossil tooth. We also note that Asscher et al. (2011) showed that modern enamel from different taxa have different extents of atomic disorder. It can therefore be expected that the more disordered modern enamel samples will be more likely to undergo diagenesis.

As the enamel grinding curves mainly shift with respect to their IRSF values and not their FWHM values, we propose quantifying the degree of alteration of enamel crystals by comparing IRSF values in the fossil sample to those in the modern sample of the same taxon for an arbitrary FWHM value of $100 \mathrm{~cm}^{-1}$. We propose using equation 1 for this purpose. Table II shows the degrees of alteration in percent of the fossil enamel samples analysed in Figure 4. The IRSF value at FWHM is calculated from the trend line equation.

Equation (1):

Degree of Enamel Enamel Alteration $[\%]=\frac{I R S F_{\text {altered }}-I R S F_{\text {modern }}}{I R S F_{\text {modern }}} * 100$

\section{Conclusions}

Here we show that the grinding curve approach can provide detailed information on the states of preservation of fossil vertebrate tissues containing carbonate hydroxyapatite. The study also shows that enamel crystals do undergo diagenetic alteration, and that this needs to be taken into account when using fossil enamel for past reconstructions.

\section{Acknowledgements}

We thank Prof Kris Poduska and Dr Lior Regev for their advice. We thank Profs Ron Shahar from the Hebrew University for the modern teeth and Dr. Hadas Motro from the Hebrew University for the archaeological teeth from Ateret and Neve Yarak. We thank Prof Aren Maeir from Bar Ilan University and Prof Israel Finkelstein from Tel Aviv University for the archaeological bones from Meggido and Tel es-Safi. We thank Prof Avi Gofer and Dr. Ran Barkai for the teeth from Qesem. Partial funding was provided by the Kimmel Center for Archaeological Science, Weizmann Institute of Science and the European Research Council under the European Community's Seventh Framework Programme (FP7/2007-2013) / ERC grant agreement $n^{\circ} 229418$.

\section{References}

Asscher, Y. and Weiner, S. et al., 2011 - Variations in Atomic Disorder in Biogenic Carbonate Hydroxyapatite Using the Infrared Spectrum Grinding Curve Method. Advanced Functional Materials (In Press).

Britton, K. and Grimes, V. et al., 2009 - Reconstructing Faunal Migrations Using Intra-tooth Sampling and Strontium and Oxygen Isotope Analyses: A Case Study of Modern Caribou (Rangifer tarandus granti). Journal of Archaeological Science 36: 1163-1172.

Dauphin, Y. and Montuelle, S. et al., 2007 - Estimating the preservation of tooth structures: towards a new scale of observation. Journal of Taphonomy 5: 43-56.

Eanes, E. D. and Reddi, A. H., 1979 - Effect of Fluoride on Bone-Mineral Apatite. Metabolic Bone Disease \& Related Research 2: 3-10.

Feranec, R. S. and MacFadden, K. B. J., 2000 - Evolution of the Grazing Niche in Pleistocene Mammals from Florida: Evidence from Stable Isotopes. Palaeogeography Palaeoclimatology Palaeoecology 162: 155-169.

GRÜN, R. 2001 - Trapped charge dating (ESR, TL, OSL). Handbook of Archaeological Sciences. D. R. Brothwell and A. M. Pollard. Chichester, John Wiley \& Sons: 47-62.

Hedges, R. E. M. and LeeThorp, J. A. et al., 1995 - Is tooth enamel carbonate a suitable material for radiocarbon dating? Radiocarbon 37: 285-290.

Lee-Thorp, J. 2002 - Two Decades of Progress Towards Understanding Fossilization Processes and Isotopic Signals in Calcified Minerals. Archaeometry 44: 435-446.

Lee-Thorp, J. and Sponheimer, M., 2003 - Three Case Studies Used to Reassess the Reliability of Fossil Bone and 
Enamel Isotope Signals for Paleodietary Studies. Journal of Anthropological Archaeology 22: 208-216.

Longinelli, A. 1984 - Oxygen Isotopes in Mammal Bone Phosphate: A New Tool for Paleohydrological and Paleoclimatalogical Research. Geochimica et Cosmochimica Acta 48: 385-390.

LuZ, B. and Kolodny et al., 1984 - Fractionation of Oxygen Isotopes Between Mammalian Bone-phosphate and Environmental Drinking Water. Geochimica et Cosmochimica Acta 48: 1689-1693.

Milton, G. M. and Kramer, S. J. et al., 1997 - Cl 36- A Potential Paleodating Tool. Nucl. Instr. Methods B123: 371-377.

Poduska, K. M., Regev, L., Boaretto, E., Addadi, L., Weiner, S., KroniK, L. and Curtarolo, S. , 2010 - Decoupling Local Disorder and Optical Effects in Infrared Spectra: Differentiating Between Calcites with Different Origins. Advanced Materials n/a. doi: 10.1002/adma.201003890.

Posner, A. S. 1969 - Crystal Chemistry of Bone Mineral. Physiological Reviews 49: 760-780.

Price, T. D. and Grupe, G. et al., 1994 - Reconstruction of Migration Patterns in the Bell Beaker Period by Stable Strontium Isotope Analysis. Applied Geochemistry 9: 413-417.

Regev, L. 2010 - Distinguishing Between Calcites Formed by Different Mechanisms Using Infrared Spectrometry: Archaeological Applications. Journal of Archaeological Science 37: 3022-3029.

Roche, D. and SEgalen, L.et al., 2010 - Preservation Assessment of Miocene-Pliocene Tooth Enamel from Tugen Hills (Kenyan Rift Valley) Through FTIR, Chemical and Stable-isotope Analyses. Journal of Archaeological Science 37: 1690-1699.

Ruppin, R. and Englman, R., 1970 - Optical Phonons of Small Crystals. Reports on Progress in Physics 33: 149-180.

Sponheimer, M. and J. A. LeE-Thorp, 1999 - Alteration of Enamel Carbonate Environments During Fossilization. Journal of Archaeological Science 26: 143-150.

Stiner, M., Kunn, S. et al., 1995 - Differential Burning, Recrystallization, and Fragmentation of Archaeological Bone. Journal Archaeological Science 22: 223-237.
Surovell, T. A. and Stiner, M. C., 2001 - Standardizing Infrared Measures of Bone Mineral Crystallinity: An Experimental Approach. Journal of Archaeological Science 28: 633-642.

Termine, J. D. and Posner, A. S., 1966 - Infra-red Determination of Percentage of Crystallinity in Apatitic Calcium Phosphates. Nature 211: 268-270.

Trueman, C. N. G. and Behrensmeyer, A. K. et al., 2004 Mineralogical and Compositional Changes in Bones Exposed on Soil Surfaces in Amboseli National Park, Kenya: Diagenetic Mechanisms and the Role of Sediment Pore Fluids. Journal Archaeological Science 31: 721-739.

WANG, Y. and Cerling, C. E., 1994 - A Model of Fossil Tooth and Bone Diagenesis: Implications for Paleodiet Reconstruction from Stable Isotopes. Paleogeography, Paleoclimatology, Paleoecology 107: 281-289.

WANG, Y. and WANG, X. M. et al., 2008 - Stable Isotopes in Fossil Mammals, Fish and Shells from Kunlun Pass Basin, Tibetan Plateau: Paleo-climatic and Paleo-elevation Implications. Earth and Planetary Science Letters 270: 73-85.

WeIner, S. 2010 - Microarchaeology. Beyond the Visible Archaeological Record. New York, Cambridge University Press.

WeIner, S. and BAR-Yosef, O., 1990 - States of Preservation of Bones from Prehistoric Sites in the Near East: A Survey. Journal Archaeological Science 17: 187-196.

WeINER, S. and WAGNER, H. D., 1998 - The material bone: structure- mechanical function relations. Annual Review of Materials Science. 28: 271-298.

Wild, E. M. and Teschler-Nicola, M. et al., 2005 - Direct Dating of Early Upper Palaeolithic Human Remains from Mladec. Nature 435: 332-335.

Zazzo, A. and Lecuyer, C. et al., 2004 - Diagenesis and Reconstruction of Paleoenvironments: A Method to Restore Original $\delta^{18} \mathrm{O}$ Values of Carbonate and Phosphate from Fossil Tooth Enamel. Geochimica Cosmochimica Acta 68: 2245-2258. 